\title{
THE REAGAN ADMINISTRATION AS THE ORIGIN OF THE SHIFT IN AMERICAN EDUCATION FROM
}

\section{CITIZEN BUILDING TO CONSUMER BUILDING}

\section{Alexander Davis}

Current American education is comprised of and influenced by a myriad of complex legislative, technological, and cultural representations of consumption, however this historic-educational study specifically examines how the Reagan administration discursively initiated the consumerizing educational framework. While existing research studies the neoliberal implications on education, this study addresses the neoliberal reforms under President Reagan within the discursive paradigm of its consumerizing impact. By using Critical Discourse Analysis on a selection of Presidential proclamations, speeches, and national educational reports, this study examines and elucidates how the Reagan administration created the consumerizing framework for American education. By understanding the results through the Frankfurt School concept of integration and expanding on Bowles and Gintis' educational theory, this study argues that Reagan's reforms created a consumerizing framework in American education.

Keywords: Consumerism, neoliberalism, American education, history/theory of education

The corporate presence is prevalent in most contemporary American schools. Today, school busses contain fast food advertisements, gymnasiums advertise sports drinks and athletic clothing brands, and school hallways offer accessible and quick refreshments featuring gigantic soda-designed vending machines. However, student learning is also directly affected inside the classroom as oil companies provide environmental science learning materials, fast food companies design physical and health education programs, and teachers are reprimanded for allowing students to complete projects instead of watching in-class televised commercials. Ultimately, American public schools are being used to accrue private profit (Saltman \& Goodman, 2011). Similarly, school choice is also increasingly the proposed solution for improving 
American educational performance. As a direct result of school choice, schools compete to attract more pupils to their school. The consequence of this competition is Hobbesian. Some schools struggle, go bankrupt and shut down, while others flourish and dominate the school market. This process of success and failure is fundamentally dependent upon 'consumer satisfaction.' In this article, I argue that corporate involvement in education, increased school choice, and resulting school competition have had a consumerizing impact on students that began with President Ronald Reagan. I am specifically interested in how Reagan's discourse enabled this consumerization to occur in American schools.

Consumerization is a term that refers to the ongoing institutional process of situating individuals in an environment (material or discursive) wherein they are perceived, treated, and encouraged as consumers. This process is a form of social integration (Marcuse, 1964) and a process of forming a type of social subject (Fairclough, 2013). That said, how and when did this process of consumerization originate in American schools?

While modern American education policy regularly emphasizes the need for corporate involvement in education, school choice, and school competition, it was President Ronald Reagan who specifically pioneered these practices. Educational historian Joel Spring (1997) explains that the 1980s 'excellence movement', motivated by Reagan policies, greatly enhanced the corporate role in American education. Alex Molnar (1996) also reports that between 1984 and 1989 school districts with schoolbusiness partnerships increased from $17 \%$ to $51 \%$. Further, de Alba, GonzálezGaudiano, Lankshear, and Peters (2010) suggest that the Reagan initiated school choice/competition supported at the Federal level relegated education to a service susceptible to market rules.

This study both contributes to an understanding of neoliberalism and American education and enhances an understanding of late modernity. While the effects of the American neo-liberalization of education are heavily studied and debated by academics, this study is unique in that it studies the origins of the studentconsumerizing framework and addresses the discursive paradigm of its consumerizing impact. Using Critical Discourse Analysis (CDA) to examine a selection of Presidential proclamations, speeches, and national educational reports, and presenting these findings through a Frankfurt Schools lens, this study demonstrates how the Reagan administration created the consumerizing framework for American education.

\section{Methods}

This study used a CDA methodology to examine how the Reagan administration discursively enabled and legitimated the consumerizing educational framework. Specifically, this study specifically adhered to the discourse-historical approach of CDA put forward by Fairclough and Wodak (1997). This approach employed a socio- 
diagnostic critique that uses "background and contextual knowledge and embeds the communicative or interactional structures of a discursive event in a wider frame of social and political relations, processes and circumstances" (Wodak \& Meyer, 2001, p. $65)$. The discourse was contextualized within the American endeavor to corporatize/privatize public education and as well as other economic considerations.

The analysis ultimately followed the five stages outlined by Wodak and Meyer (2001) in that it:

addresse[d] a social problem with a semiotic aspect; 2) identifie[d] obstacles being tackled (problematization); 3) consider[ed] if the problem [was] needed by the social order; 4) identifie[d] possibilities for change; 5) critically reflect[ed] on the analysis (p. 125-127).

An analysis grid was used with some facets of CDA which I accumulated from Fairclough (2004; 2013). These tenants were selected because they are concerned with a) the method in which ideology and power is represented, exercised, and legitimatized, b) how meaning is articulated and created, c) how values are revealed in language, and d) how citizens are situated within the discursive process.

My analysis focused the following ten aspects of CDA: discourse; genre; style; recontextualization; public sphere; generic structure; types of meaning; governance; legitimation; and, evaluation. Each is defined below.

Discourse is multifaceted. It is comprised of the many ways of representing aspects of the world, associated values and beliefs, and fundamentally, "they are also projective, imaginaries, representing possible worlds which are different from the actual world, and tied in to projects to change the world specific directions" (Fairclough, 2004, p. 124).

Genre is the semiotic way of acting and interacting (Fairclough, 2013). Our concern with genre then was how Reagan or the educational reform proposal interacted with the audience or reader. Fairclough (2004) explains that, "when we analyse a text or interaction in terms of genre, we are asking how it figures within and contributes to social action and interaction in social events" (p. 65).

Style is important because it considers how one identifies oneself and subjects. For example, Reagan identifies himself and others when publicly addressing the need for school choice. Discourse, genres, and styles together project specific forms of meaning (Fairclough, 2013).

Recontextualization is a social practice of taking social elements from one social context and applying it to another (Fairclough, 2004, p. 33); our concern here is how business values were applied to the educational discourse. 
Public sphere is the environment wherein citizens engage in social discussion and association (Fairclough, 2004, p. 44). As this study does not focus on the perceptions and deliberations of citizens directly, public sphere in this context addresses how citizens are discursively recommended to engage with one another.

Generic structure pertains to the physical organization of a text (Fairclough, 2004, p. 73) and types of meaning analyzes how discourse applies different meanings to social actions, representations of the world, and social identities (Fairclough, 2004). Analyzing types of meaning is to study the relationship of the item of discourse "to the wider physical and social world, and to the persons involved in the event" (Fairclough, 2004, p. 27).

Fairclough articulately describes governance as the "Activity within an institution or organization directed at managing or regulating social practices" (Fairclough, 2004, p. 217), which is helpful in analyzing the forms of recommended management in American education.

Legitimation considers how Reagan and his administration justify their proposed reforms. Lastly, evaluation connotes the ways in which discourse places value assumptions into its meanings (Fairclough, 2004, p. 215). These selected CDA aspects contributed towards our socio-historical understanding of the origin of the educational consumerization process.

Sample

The discourse sample comprised of a total of 16 items. Of this sample, 14 are oral events -6 comprisied of Presidential Proclamations and 8 Public Addresseswhile the remaining 2 are textual educational reports produced by Reagan's administration. The 14 oral events were selected for the sample because of their focus on either the role of private sector involvement in education or school choice. The two educational reform reports used were $A$ Nation at Risk: The Imperative for Educational Reform (National Commission on Excellence in Education, 1983) and Action for Excellence: A Comprehensive Plan to Improve Our Nation's Schools (Task Force for Education on Economic Growth, 1983). A Nation at Risk was selected for its extreme influence on subsequent educational reform. For example, following the publication of A Nation at Risk, Reagan devoted "51 major speeches on education" (Bell, 1986, p. 493). Action for Excellence was selected because of its overarching recommendation for corporate involvement in education.

\section{Conceptual Framework: The Frankfurt School}

The Frankfurt School perspective of Herbert Marcuse and Douglas Kellner provided the conceptual framework. The writings of both are specifically concerned with how individuals become integrated into the capitalist system and how certain facets of capitalism (consumerism, advertising, etc.) stabilize the capitalist system 
(Marcuse, 1964; Kellner, 2007). Marcuse and Kellner perceive consumerism and advertising as fundamental strategies which integrate individuals into the capitalist system. Understanding the consumerization of students as an economic strategy, predicated upon the centrality of consumerism in advanced industrial societies (Marcuse, 1964), Marcuse and Kellner frame the study in its relevant economic context. Using the Frankfurt School concept of integration, this study positions Bowles and Gintis' argument (1976) within consumerist prevalence. In their concept of the correspondence principle, Bowles and Gintis explain how schools are modeled along a capitalist organization of labour and reinforced through discipline. According to these researchers, the objective of capitalist education systems is to produce an organized and disciplined labour force. However, I applied my findings upon the premise that American education developed to produce an organized and disciplined consuming force. By integrating students as consumers, capitalism is sustained and reinforced by consumerism.

\section{Results}

The results presented here discuss the four most significant discourse aspects to emerge from the analysis. They are: 1) style; 2) types of meaning; 3) governance; 4) and, legitimation. The other six CDA aspects in the analysis grid did not yield a cohesive theme for incorporation. Each of the four significant aspects is discussed in a corresponding section below. Each explains the significant, and sometimes overlapping themes that operated to distinguish and legitimize Reagan's educational policies when compared to his predecessors, to increase the presence of the private sector in education, and to enhance parental choice and school competition.

\section{Style: Reagan's Predecessors as Misguided and Reagan as a Rescuer}

Examining style in discourse is significant because style generates "a particular social ordering of relationships between different ways of making meaning" (Fairclough, 2013, p. 180). Reagan most commonly characterized his style as being one of a rescuer or as leading the rescue/restoration of education. He presented himself as a rescuer in 10 out of the 14 oral events analyzed. This self-presentation by Reagan often distinguished his concept of education from that of his predecessors because rescue/restoration presumes a damaged state in need of saving/fixing. Indeed, Reagan often referred to his predecessors' policies as resulting in a need for the rescue of education. Although Reagan most often portrayed himself as a rescuer when distinguishing and legitimating his reforms from that of his predecessors, he also applied this identification to his reform suggestions specifically.

Forms of rescue in Reagan's style addressed correcting the bureaucratic misdirection of his predecessors, restoring the parental right to choosing education, and renewing the American spirit through restoring individual (business) involvement in public education. For example, Reagan applied the identity of rescuer to the private 
sector by explaining to business leaders that, "You have made a difference for your country and for millions of your countrymen. You have helped renew and enrich America by awakening one of her oldest and most noble traditions" (Reagan, 1985c). This example shows how Reagan rhetorically suggests that his predecessors silenced American tradition, and how under his leadership the American people are invited to rescue education from the private sector and return it to its former and rightful place. Another example of how Reagan associated himself and his reforms as being a rescuer is in this excerpt from Remarks at a Briefing for the White House Workshop on Choice in Education (1989). Here he states that,

For too long, I think, we were content as Americans to imagine that our nation and our society were so inherently strong and successful that they could continue to run on automatic pilot. The schools had done well and should continue to do well; we could turn our attention elsewhere. Well, if we were on automatic pilot in the past, we've learned we have to work the controls by ourselves every day. And that's why a choice in education is so important.

In this example Reagan associates rescuing American society from 'automatic pilot' by restoring parental choice in education. The emphasis on the importance of choice in education extends beyond simply the educational environment and instead associates it with a benefit for all of society. These simple examples highlight how Reagan styled himself as a rescuer and characterized his reforms as rescuing education and American society.

According to the style of Reagan's discourse, he presented himself as a rescuer fighting for the rebirth of the American spirit. By highlighting a need for the rebirth of the American spirit, Reagan implied that his predecessors had damaged the American spirit. His dramatic lexicon employed language such as "great renewal" (Reagan, 1983c), "restoring the American educational system to its place of preeminence among nations of the world" (Reagan, 1984a), "spirit of renewal that's underway" (Reagan, 1984b), and "You have helped renew and enrich America by awakening one of her oldest and most noble traditions" (Reagan, 1985c). Further, in depicting education as on the cusp of renewal, Reagan related this renewal as rescuing education from the apparent misguided, and quite literally damaging strategies of his predecessors

Types of Meaning: Enhancing the Parental and Private Sector Role in Education

Types of meaning comprise three meaning components: 1) action, 2) representation, and, 3) identification. The actional components most commonly encouraged the enhancement of both the private sector's role in education and parental right to select schools. In analyzing this discourse, one may examine how Americans acted on Reagan's discourse or "operationalized" (Fairclough, 2013, p. 180) it. Accordingly, the action recommendations typically took the form of directly suggesting that more private sector involvement was needed and that more space for 
parental choice was required. A simple example of this is found in Proclamation 5112-National Year of Partnerships in Education 1983-1984 (Reagan, 1983a), wherein Reagan states, "In order to encourage this trend, I call upon businesses, organizations, individuals, and agencies to become involved with their local schools." Indeed, the very proclamation of a year dedicated to forming partnerships in education is a pragmatic approach to achieving an action type of meaning. Although there were suggestions from some discourse sources for more standards, most of evidence recommended inviting private sector collaboration and enhancing parental choice.

Representations are imaginaries (Chiapello \& Fairclough, 2002), which materialize as new forms of social practice. The representational aspect of types of meaning largely perceived federal government as detrimental to education. For example, Reagan explained that,

Dr. Eileen Gardner, has written: "The record shows that when control of education is placed in Federal hands it is not control by the people, but by small, yet powerful lobbies motivated by self-interest or dogma. When centralized in this way, it is beyond the control of the parents and local communities it is designed to serve. It becomes impervious to feedback. (Reagan, 1985b)

Federal government was presented as a negative force in education. Instead, as a public institution, Reagan advocated that it should be under the control of the public. The private sector and parental choice in education would instead replace the role of the Federal government. Reagan directly emphasizes the necessity of this replacement by stating that, "There are things the Federal Government can and must do to ensure educational excellence, but bigger budgets are not the answer...the focus of our agenda is, as it must be, to restore parental choice and influence and to increase competition between schools" (Reagan, 1983b). Private sector leaders were also repeatedly included in the neoliberal representation of education. Reagan explained the pertinent role of the private sector by explaining that, "The crystal tetrahedrons that I am awarding today symbolize how the fusion of the private, public, and non-private sectors can form a solid base. Only by working together and finding some private solutions to public problems can we restore the strong balance needed for the future health of our Nation" (Reagan, 1985c). This example shows how his brand of educational reform represents a beneficial economic-educational relationship. Reference to an economic-educational relationship appeared numerously throughout his discourse and can be accepted as the overarching representation of the society he had in mind. In A Nation at Risk (1983), it argues that, "The twin goals of equity and high-quality schooling have profound and practical meaning for our economy and society, and we cannot permit one to yield to the other in principle or practice" (NCEE, p. 13). Action for Excellence (1983) clearly relates private sector involvement in education as beneficial to the economy by suggesting that, "If the business community gets more involved in both the design and delivery of education, 
we are going to become more competitive as an economy" (TFEEG, p. 17). It is important to remember that during the 1980s, the USA was underperforming on the international stage, and to ensure that blame would not be assigned to Reagan's administration for the current economic situation, the blame needed to be deflected to the mismanagement of Reagan's predecessors. The neoliberal narrative not only deflected blame and re-assigned it "correctly", the narrative provided hope for a better economic future by associating improved education (and therefore the economy) with private sector involvement, choice and competition.

Lastly, Reagan gave new identities to two groups: the private sector and his predecessors. First, the private sector was typically identified as a beneficial force for education because it embodied the essence of the American spirit. For example, Reagan explained that, "Our country is great because it is built on principles of selfreliance, opportunity, innovation, and compassion for the others. Private sector initiatives embody this spirit and are a vital part of the Nation's character" (Reagan, 1985c). If American education was declining, the private sector could rejuvenate schools, and consequently the economy would improve. Second, Reagan also consistently identified his predecessors as being misguided and detrimental to education. In one example, Reagan alludes to his predecessors as abandoning the vision of the Founding Fathers,

In the past 7 years, our Administration has worked to restore a vision of government that was the Founders' own-a vision of a free and self-reliant people, taking responsibility for its own welfare and progress through such time-tested means as individual initiative, neighborhood and community cooperation, and local and State self-government. The return of responsibility and authority to the individual American is now leading to a virtual renaissance in America of liberty, productivity, prosperity, and self-esteem (Reagan, 1988).

By referring to restoring a vision, Reagan suggests that his predecessors abandoned the vision of the Founding Fathers. Accordingly, the construction of identity stems from the ideological underpinnings of specific discourses (Fairclough, 2004 , p. 9). Regarding Reagan's policies, the ideological underpinning was a neoliberal reformulation of society. This is just one example of identifying the predecessors as detrimental to American education and society, but the discourse is rife with this characterization.

\section{Governance: Regulating Education through Choice and Competition}

Reagan very clearly perceived Federal regulation as antithetical to educational improvement. He often offered choice and competition as beneficial forms of governance. He gave credence to choice and competition as regulating factors that would increasingly improve education. In suggesting that choice and competition were solutions to the educational crisis, Reagan also linked his predecessors to Federal government infringement having caused the educational crisis. Simply put, it seems 
that the logic followed: Federal government overspending/regulation caused this crisis, parental choice and competition rely on individual preference and not Federal government, therefore replacing Federal government regulation with a non-Federal government regulatory force will solve the crisis. Accordingly, Reagan explained that,

Choice in education is the wave of the future because it represents a return to some of our most basic American values. Choice in education is no mere abstraction. Like its economic cousin, free enterprise, and its political cousin, democracy, it affords hope and opportunity. Can anyone doubt that, after hearing these splendid young people testify about how choice has changed their lives? Choice recognizes the principle that there is no one best way for all of us. It allows schools to excel at something special, rather than trying, and failing, to be all things to all people. (Reagan, 1989, p. x)

Like a product, Reagan explains that schools will specialize in a specific area and satisfy the needs of specific people. It was believed that choice and competition would therefore satisfy the needs of more people instead of attempting to satisfy the needs of all. In fact, we can correlate this suggestion for choice and competition in education to commodified products and services. In Proclamation 5417-National Consumers Week, 1986 (Reagan, 1985a), Reagan explains that "[Competition] will enable [consumers] to make wise choices whether they are shopping for food, shelter, clothing, transportation, recreation, health care, entertainment, and so on." Reagan does not explicitly identify education in this list of consumer services, but from other references to choice and competition in education we can assume that education was just another service to be shopped for. According to Reagan, the governance system of choice and competition offered greater options for the consumer; education was situated in his discourse as an object of consumption. The discourse merges governance as an economic extension by connecting choice in education with "its economic cousin, free enterprise, and its political cousin, democracy, [as] it affords hope and opportunity" (Reagan, 1989). The semiotic decision is a representational strategy (Fairclough, 2004, p. 145; Machin \& Mayr, 2012), which highlights certain aspects of identity (Machin \& Mayr, 2012, p. 77) -in this case a citizen empowered for his/her consuming function.

The recommendation to subsume choice and competition into a governance mechanism fundamentally encouraged parents/students to exercise their consuming role and ultimately represent a significant shift in American education policy.

Legitimation: Reforms Antithetical to Predecessors' and Appeal to American Tradition

Discourses impose new ways of being and new forms of social practice, and accordingly, examining the ways in which Reagan's discourse was legitimatized is imperative in explaining how it came to be operationalized. Chiapello and Fairclough (2002) explain that legitimizing educational change legitimizes neoliberalism (p. 187), 
thus, "a particular social structuring of semiotic difference may become hegemonic, become part of the legitimizing common sense" (p. 194). Since Mathison and Ross (2008) explain that privatizing and commercializing education became commonsensical to policymakers after Reagan (p. 131), it becomes necessary to analyze the ways in which Reagan legitimized a consumerizing framework. Reagan overwhelmingly legitimized his reforms in two ways. First, he correlated the decline in educational performance with the strategies of his predecessors. In doing so he explained how the overspending of his predecessors and the Federal government's control over education induced educational deterioration, which acted to legitimize his reforms because his reforms were opposite to his predecessors. Thus, the rational for reducing educational funding was legitimized because his predecessors shoveled money into education and subsequently educational performance declined. This legitimation differentiated his policies from those of his predecessors and ultimately validated private sector involvement in education and the governance system of choice and competition. Simply identifying the difference between his educational policies and those of his predecessors was enough to distinguish his reforms as good ones from the bad ones of his predecessors. He further legitimized this policies by arguing that his reforms were based upon American tradition or compatible with the vision of the Founding Fathers, while his predecessors' policies were not.

Second, Reagan legitimized his reforms by appealing to American sensibilities, such as American spirit, tradition, and former greatness. For example, Reagan referred to choice in education as "The return of responsibility and authority to the individual American is now leading to a virtual renaissance in America of liberty, productivity, prosperity, and self-esteem" (Reagan, 1988). Another example is how Reagan emphasized the private sector as embodying characteristics of the American spirit-to deny private sector involvement in education was consequently to reject the American spirit. When Reagan appeals to American tradition to validate his policies, this form of legitimation is called authorization (Van Leeuwan, 2008). In referring to the previous abandonment of American tradition, Reagan constructs himself in the role of the rescuer; he is ultimately restoring American traditional values to education. The negative portrayal of Reagan's predecessors as reckless spenders positioned them in opposition to American values and fundamentally legitimized Reagan's initiatives to structure education with private sector involvement.

\section{Conclusion}

Consumerism and advertising are necessary for stabilizing capitalism (Marcuse, 1964; Kellner, 1983; Harvey, 1989). Similarly, education has been perceived as an institution that reproduces the conditions necessary for the hegemony of capitalism (Bowles \& Gintis, 1976; Greaves, Hill, \& Maisuria, 2007; Althusser, 2014). Bowles and Gintis (1976) extrapolated the connection between American education and the creation of an effective labour force-revealing how schools are modeled along a capitalist organization of labour and reinforced through discipline. In explaining the 
development of this educational structuring, Gintis and Bowles explain that, "Major periods of educational change are responses to alternatives in the structure of economic life associated with the process of capital accumulation" (1976; p. 199). The launch of Reagan's reforms in 1983 mirrors the significant decline in domestic manufacturing employment (See Figure 1).

This decline in manufacturing coincides with the rise of the service sector (Plunkert, 1990; Bjork, 1999, p. 291). Accordingly, during this shift Reagan

Figure 1: Manufacturing Employee Data in the United States between January 1980 and January 1989

(United States Department of Labor, 2016)

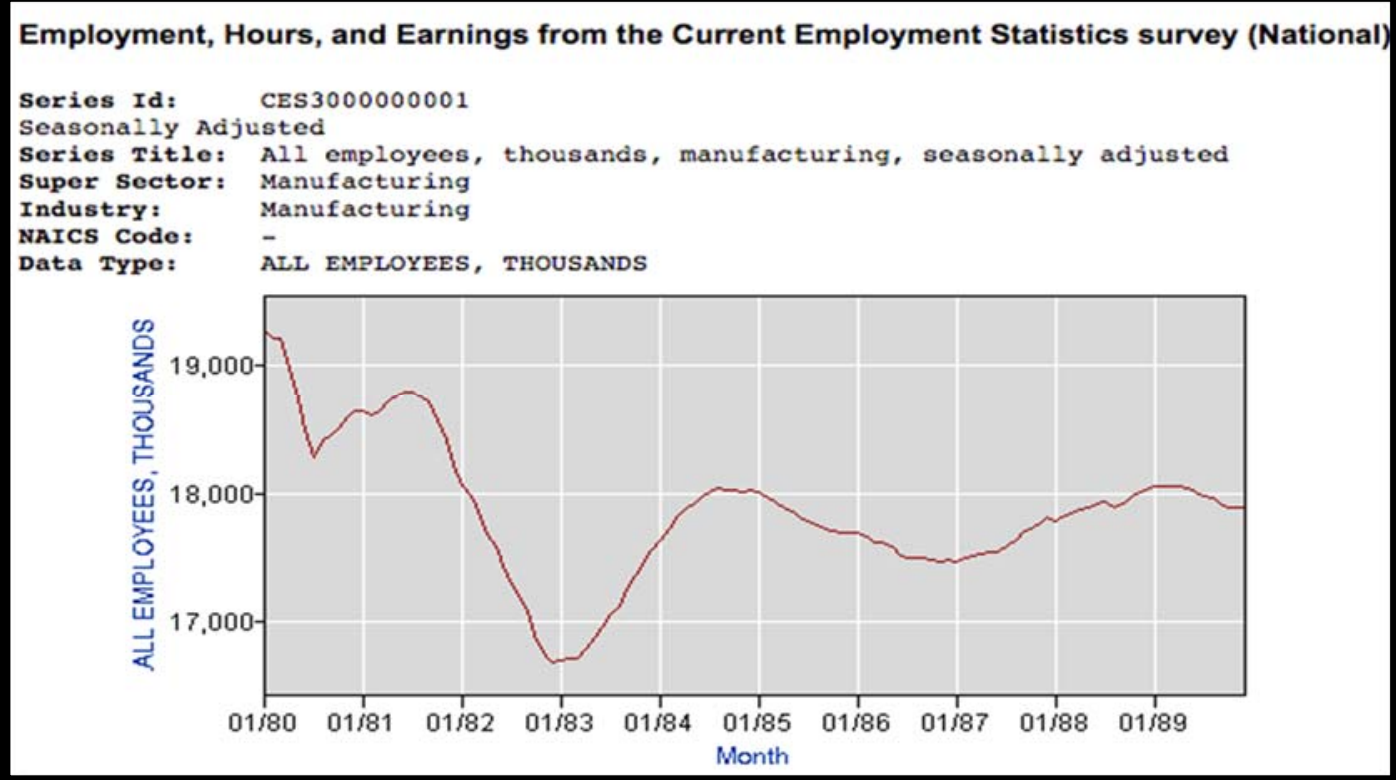

discursively positioned education within the neoliberal environment of enhanced private sector involvement, parental choice, and within the governance of competition. Consequently, Reagan's discourse functioned to integrate (Marcuse, 1964; Kellner, 2007) students, as consumers, into the capitalist system. Similarly, Richard Wolff (2005) explains that the ideological language of Reagan's 1983 national education reform reports had an integrating function (p. 230). While Reagan's reports and discourse serve to integrate the public, it also shaped the form and content of future educational discourse (Stedman, 1987; Hass, 2008; Collin \& Ferrare, 2015). Reagan enabled the consumerizing framework by: 1) styling himself and his reforms as rescuer/rescuing, 2) developing new types of meaning that reflected an emphasis on neoliberalization, 3) imposing an educational governance of choice and competition, and 4) legitimizing his reforms by connecting educational decline with the policies of his predecessors and appealing to American sensibilities. In their totality, these four themes helped to enhance the corporate presence in education and to impose school competition and greater school choice initiatives. Corporate opportunists gained deep 
access to students as consumers and the entire school choice movement became predicated on parents and students exercising their role as consumers.

\section{References}

de Alba, A., González-Guadiano, E., Lankshear, C. \& Peters, M. (2000). Curriculum in the postmodern condition. New York, NY: Peter Lang Publishing, Inc.

Althusser, L. (2014). On the reproduction of capitalism: Ideology and ideological state apparatuses. New York, NY: Verso.

Bell, T. H. (1986). Educational policy development in the Reagan administration. Phi Delta Kappan, 67(7), 487-494.

Bjork, G. C. (1999). The way it worked and why it won't: Structural change and the slowdown of U.S. economic growth. Westport, CT: Praeger Publishers.

Bowles, S. \& Gintis, H. (1976). Schooling in capitalist America: Educational reform and the contradictions of economic life. New York, NY: Haymaket Books.

Chiapello, E. \& Fairclough, N. (2002). Understanding the new management ideology: A transdisciplinary contribution from critical discourse analysis and new sociology of capitalism. Discourse \& Society, 13(2), 185-208.

Collin, R. \& Ferrare, J. (2015). Rescaling education: Reconstructions of scale in President Reagan's 1983 State of the Union Address. Journal of Education Policy, 30(6), 796-809.

Fairclough, N. (2004). Analysing discourse: Textual analysis for social research. New York, NY: Routledge.

Fairclough, N. (2013). Critical discourse analysis and critical policy studies. Critical Policy Studies, 7(2), 177-197.

Fairclough, N. \& Wodak, R. (1997). Critical discourse analysis, in T. van Dijk, Discourse Studies: A Multidisciplinary Approach. London, England: SAGE Publications, Inc.

Greaves, N., Hill, D., \& Maisuria, A. (2007). Embourgeoisment, immiseration, commodification-Marxism revisited: a critique of education in capitalist systems. Journal for Critical Education Policy Studies, 5(1), 38-72.

Harvey, D. (1989). The condition of postmodernity: An enquiry into the origins of cultural change. Cambridge, MA: Blackwell Publishers. 
Hass, E. (2008). Propaganda, in D. Gabbard, Knowledge \& Power in the Global Economy: The Effects of School Reform in a Neoliberal/Neoconservative Age. New York, NY: Lawrence Erlbaum Associates.

Kellner, D. (1983). Critical theory, commodities and the consumer society. Theory, Culture, \& Society, 1(3), 66-83.

Kellner, D. (2007). The Frankfurt school, in, T. Edwards, Cultural Theory: Classical and Contemporary Positions. London, England: SAGE Publications, Inc.

Machin, D. \& Mayr, A. (2012). How to do critical discourse analysis. London, England: SAGE Publications, Inc.

Marcuse, H. (1964). One-dimensional man: Studies in the ideology of advanced industrial society. Boston, MA: Beacon Press.

Mathison, S. \& Ross, E. W. (2008). Battleground: Schools. Westport, CT: Greenwood Press.

Molnar, A. (1996). Giving kids the business: The commercialization of America's schools. Denver, CO: Westview Press.

National Commission on Excellence in Education. (1983). A nation at risk: The imperative for educational reform. Washington, D.C.: U.S. Government Printing Office.

Plunkert, L. M. (1990). The 1980's: A decade of job growth and industry shifts. Monthly Labor Review, 113(9), 3-16.

Reagan, R. (1983a). Proclamation 5112-National year of partnerships in education 1983-1984, The American Presidency Project, http://www.presidency.ucsb.edu/ws/index.php?pid=40576.

Reagan, R. (1983b). Radio address to the nation on education, The American Presidency Project, http://www.presidency.ucsb.edu/ws/?pid=41259.

Reagan, R. (1985a). Proclamation 5417-National consumers week, 1986, The American Presidency Project, http://www.presidency.ucsb.edu/ws/?pid=38122.

Reagan, R. (1985b). Remarks at the annual meeting of the national association of independent schools, The American Presidency Project, http://www.presidency.ucsb.edu/ws/index.php?pid=38263.

Reagan, R. (1985c). Remarks at the presentation ceremony for the "C" flag awards, The American Presidency Project, http://www.presidency.ucsb.edu/ws/?pid=38773. 
Reagan, R. (1988). 1988 legislative and administrative message: A union of individuals, The American Presidency Project, http://www.presidency.ucsb.edu/ws/?pid=36046.

Reagan, R. (1989). Remarks at a briefing for the white house workshop on choice in education, The American Presidency Project, http://www.presidency.ucsb.edu/ws/?pid=35348.

Saltman, K. J. \& Goodman, R. T. (2011). Rivers of fire: BPAmoco's iMPACT on education, in K. J. Saltman \& D. A. Gabbard, Education at Enforcement: The Militarization and Corporatization of Schools. New York, NY: Routledge.

Spring, J. (1997). Political agendas for education: From the Christian coalition to the green party. Mahwah, NJ: Lawrence Erlbaum Associates, Inc.

Stedman, L. C. (1987). The political economy of recent educational reform reports. Educational Theory, 37(1), p. 69-76.

Task Force on Education for Economic Growth. (1983). Action for excellence: A comprehensive plan to improve our nation's schools. Denver, CO: Education Commission of the States.

United States Department of Labor (2016). Employment, hours, and earnings from the current employment statistics survey (national). Bureau of Labor Statistics, https://data.bls.gov/pdq/SurveyOutputServlet.

Van Leeuwan, T. (2008). Discourse and practice: New tools for critical discourse analysis. New York, NY: Oxford University Press.

Wodak, R. \& Meyer, M. (2001). Methods of critical discourse analysis. Thousand Oaks, CA: SAGE Publications, Inc.

Wolff, R. D. (2005). Ideological state apparatuses, consumerism, and U.S. capitalism: Lessons for the left. Rethinking Marxism, 17(2), 223-235. 